\title{
Peter Klepec: from a (Local) Hero to an Allegory (National) of Weakness *
}

Keywords: Peter Klepec, hero, myth, border, nationalism

DOI: $10.4312 /$ ars.9.1.204-226

\section{Preface}

Myth is a subject of study in almost all the disciplines of social sciences and humanities (theology, philosophy, anthropology, psychology, history, literary theory, etc.) (Hrženjak, 1999, 45), therefore it cannot be defined only by one single definition. In very broad terms, we could say that myth is "a story about something significant" (Segal, 2004, 5), whose mission is to give meaning and clarify things which it "surrounds with an aura of universality, absolute truth" (Jocić, 2003, 186).

The word mythology means both "narrative forms, stories that are known to us, as well as interpretive discourses" (Detienne, 2008, 10). Mythology is a characteristic of all, past and present, human groups (Velikonja, 1996, 21; see also Armstrong, 2005). It is a "complex system of notions, beliefs, and symbols that a certain social group fosters", in short, a manner of "self-comprehension" and "self-presentation" of a particular society (Velikonja, 1995, 26). Each social segment has its own myth; therefore, to understand what is happening in a society we must be familiar with its mythology (Velikonja, 1996, 11-12).

Modern (political) mythology consists of traditional and ideological myths, whereby the traditional myth forms a foundation or base; and ideological myth is its derivation (Velikonja, 1996, 28). Traditional myths are rooted in the collective memory and are historically more or less constant and relatively unchanging. They are internalized (endogenous) means of "thinking, valuation and functioning of a society" which derive from ancient traditions. The ideological myths are exogenous - that is, they comprise a story, which is produced by an interested group with a focus toward the future. Traditional myth poeticizes the world, while the ideological myth politicizes it (Velikonja, 1996, 7-28). The traditional myths include ancient stories about heroes, such as Peter Klepec who is dealt with in this

The Slovene version of this article is available on: http://revije.ff.uni-lj.si/arshumanitas. / Slovenska različica članka je dosegljiva na http://revije.ff.uni-lj.si/arshumanitas. 
present article. The ideological myths supplement the story or interpret it in its own terms or anew.

Mythology is directed towards a clearly defined goal, where myths are involved stories that "mobilise, integrate, interpret, communicate" (Velikonja, 2003, 9). They are important both in the creation and strengthening of a sense of cohesion in societies, as well as in the creation and preserving of collective identities (see Svein Stugu, 2003, 3 ) and national ones as well (see, for example, Smith 1999). In promoting various identifications, the so-called heroic myths, with which it is very easy to identify, are very successful. "The image of the hero or protagonist has in human history always been an instrumental representation, which has in the light of a number of religious, political and other ideologies often served as an agent of a dominant social ideology and a reproductive means of social order" (Šaver, 2006, 72). Hourihan $(1997,2)$ finds that the stories of heroes and quest myths in today's Western culture occupy a central place. They appear in legends, tales, children's and youth adventure literature (e.g., Robinson Crusoe, Robin Hood, The Lord of the Rings), in film productions for children and adults (e.g. James Bond, Batman, Indiana Jones), and finally in computer games. They are so ubiquitous that they have become a reflection of reality (Hourihan, 1997, 14), or the individuals themselves perceive them as real. Therefore, it is probably unnecessary to emphasize the role of these myths in transferring values. However, it is not necessary that mythology, or interpretation and usage of mythology, always remain unaltered.

Detienne wrote that "the world of repetition" is "also the world of mutability" (Detienne, 2008, 86), whereby he meant the variations resulting from numerous reiterations of the same story. To slightly paraphrase his thought, we can say that the message of the mythical story with its "repetitions", or usage in different historical (or social) circumstances, varies even though the story itself (the traditional myth) does not change, whereby a large role is played out by discourse. According to Foucault, discourse is a mode of "application and design of knowledge about specific areas of practice. It is the creation of ideas, images and practices that create and enable ways of speaking, creation of knowledge and control of behaviour that are associated with objects or areas to which the discourse relates" (Hrženjak, 2002, 387). Foucault emphasizes the historical contextualization of discourse, which means that they are changing in different periods and "discursive genres" alongside with them-such as folk tales, myths and stories, and some forms of ritual interactions (Vezovnik, 2009, 9). In this way, the myth in different (or even the same) historical periods is used and interpreted differently.

The purpose of this paper is to show the changing role and diversity of interpretations of myth in time and space using the example of folk and literary hero Peter Klepec. I 
focused on the historical changes in the perception of Peter Klepec: namely, on his (local) function at the time of the Hapsburg imperial policy, the process of his nationalisation, and dilemmas that arose following the division of the Čabranka-Osilnica area; i.e., the originating area of the creation of the legend of the two countries (Croatia and Slovenia). I showed that Klepec was due to different historical circumstances and (interpretive) discourse used for different purposes. First, he served as a symbol of strength and survival in the Čabranka-Osilnica valley, and then as the Hapsburg myth that justified the existence of the monarchy facing the hostile Ottomans, and lastly as an allegory of a servile Slovene, who is always just a faithful bondsman to other masters (first under the Austro-Hungarians and then the European Union).

At the beginning of the article I observe whether Peter Klepec is a hero, and then I introduce the function of the myth of Peter Klepec through different time periods. I do not focus on the literary genre, but the role of folklore and literary figures in the creation of the local and wider Slovenian identity. In my work I used interviews and informal conversations with the inhabitants of the valley, and also a very good local expert of the situation in the valley, amateur ethnologist Marko Smole, ${ }^{1}$ which complement an otherwise descriptive and analytic article. Since the character of Peter Klepec, unlike that of Fair Vida ${ }^{2}$, King Matthias ${ }^{3}$ and Martin Krpan, ${ }^{4}$ has not been discussed in detail in Slovenian ethnology, folklore, literary, and other science, and because scientific publications on Klepec do not exist in Croatia ${ }^{5}$ either, I want to encourage further research with this paper (perhaps even as the result of a crossborder cooperation).

\section{Peter Klepec - a hero? Truth or fiction?}

The narrative hero Peter Klepec is known (and laid claim to) by the inhabitants of the Čabranka-Osilnica valley, the border area on the Croatian and Slovenian side of the border. There circulate a number of quite similar stories about him, in which a frail illegitimate child Peter becomes a strong man, whose supernatural powers help the needy and drive the enemies from these regions.

1 Marko Smole owns the Palčeva šiša ethnological collection in Plešce in Croatia. He lives in Ljubljana, but is very active in Plešce in Croatia. One of the interlocutors lives in Slovenia and two on the Croatian side of the border. Due to the wishes for anonymity of the three interlocutors, I do not cite or use their surnames in the article. I only provide their names.

2 A study on the ballad of Lepa Vida was written by Ivan Grafenauer in 1943. See also Ovsec, 1998.

3 See, for example, Grafenauer, 1951; Šmitek, 2009; Kropej, 2014.

4 See, for example, Hladnik, 2002 or / and Jazbec, 2009.

5 I obtained information for Croatia from Ana Perinić Lewis, PhD, Institute for Anthropological Research, Zagreb, who researches heroes and people with supernatural powers in the area of Gorski Kotar. 
Is (was) Peter Klepec a hero? First of all, let us take a look at the definitions provided by the Dictionary of the Slovenian Literary Language (hereinafter referred to as: SSKJ) where hero is defined as: "a man who did an exceptionally courageous, heroic deed; a champion", and as a character from Greek mythology, "someone of human and divine traits and qualities, demigod" (Bajec et al., 1994).

The SSKJ (Bajec et al., 1994) continues with the following: "a man who endures, performs feats which require great strain, sacrifice", "an exceptionally courageous, fearless man", "a man who is admired because of some inspiring quality", "a main, central character in a literary work", or "a person of whom it is recounted", and even somewhat chauvinistically, "a man which is distinguished by some trait or by some action", and lastly, "a handsome, strong man".

In his theory of the cult of the hero, Thomas Carlyle, a historian, described heroes as having a major importance for humanity, where he wrote that the history of the world is "but the biography of great men". He defined various forms of heroism characteristic of different historical periods, starting with paganism, in which heroes had been equated with the gods, and Islam ${ }^{6}$ where the hero has been "degraded" to God's envoy. In the modern era, the following come to the fore: the hero as poet (e.g., Dante), the hero as priest (e.g., Luther), scholars (e.g., Rousseau), and rulers or kings, who embody all the previous stages of heroism (Carlyle, 1913, 239). All the above mentioned heroes have in common the following: "primal courage and honesty" (Špelec, 2013, 236).

What about narrative heroes? Do they differ significantly from the aforementioned "true" heroes? Zmago Šmitek claims that a folktale hero is distinguished from the "ordinary" people by "specific physical characteristics and special abilities". Classical heroes "mimic the actions of former gods or famous ancestors", which is reflected in the mythical notion of circular time or eternal reiteration of "similar circumstances", which together with educational and national awakening content leads to the fact that the hero becomes part of the national (Slovenian) identity (Šmitek, 2005, 5). As shown below, this also happened with Peter Klepec. The hero is articulated through juxtaposed antitheses of good versus bad, positive versus negative, and as such cannot exist without the adversary (see Šmitek, 2005, 6; also Hourihan 1997). Stories of heroes are placed into a "recent past" and domestic or familiar environment. Because of their supernatural abilities (e.g., extraordinary powers), the heroes even begot a demigod status and "some mythical splendour" (Šmitek, 2005, 6) in ordinary people's eyes.

6 Carlyle uses the term "Mahometanism", which today has a pejorative connotation. Therefore, I replaced it with the word "Islam". 
Given the fact that Peter Klepec is both a folklore and literary character, let us take a look at the categorisation of literary heroes, as drawn up by Northrop Frye (2004, 39-40). He classified the heroes into five categories according to their powers. The first type of hero is a divine creature with superhuman strength and the story about him is called a myth. The next type of hero appears in legends, folk tales and fairy tales; it is a human who exceeds ordinary people and has the ability to work miracles. The third type of hero is the hero of the epic poem or tragedy that is not placed above the people, however, he is braver, stronger, and smarter than them. The fourth group covers heroes that are similar to us, or, in other words, heroes of realistic literature; and the fifth group demonstrates intellectually and spiritually below-average or ironic heroes. However, within a literary or narrative work different types of heroes can be intertwined (Zupan Sosič, 2013, 215).

You could put Peter Klepec under almost any of the described characteristics of the "true", folklore and literary heroes. Tales of Peter Klepec include characteristics of (heroic) tales, as well as fairytales. They combine realistic elements, that include: the names of places and persons, the hero's personality traits, descriptions of historical reality (that is, he serves as a shepherd, Turkish invasions), customs and fairytale elements - e.g., magical assistants (fairy, ox), the hero's miraculous powers, and the fight between good and evil, where good always triumphs (see, for example, Goljevšček, 1991, 42-46).

At the outset, the stories (which may continue in other stories about the triumph of Klepec over the Turks, ${ }^{7}$ Hungarians, etc., or it can independently form a closed narrative) are similar and describe Peter Klepec as a poor and frail boy, further underprivileged by the fact that he was an illegitimate child. To help his mother who could not provide for their livelihood, he had to work as a village shepherd. Because of his frailty, he was insulted, mocked, and beaten by other shepherds if he disobeyed. In accordance with Campbell's definition of the archetypal hero's journey or adventures, Klepec dissociates from his everyday world and ventures into the realm of the supernatural. Most often the stories depict Sveta gora (Holy Mount) "where he encounters fairytale forces" (fairy, Mary, angel, God) and "wins a decisive victory". Finally, he returns "endowed with the power to help his fellow man" (Campbell, 2007, 48-57) or the local population, and even saves the entire empire from the Turks. Depending on the source of the power of Klepec or his encounter with the Supernatural, the narratives might be divided into three groups: stories in which a Christian assistant (God, Mary, the angel) is present, those involving a

7 In this paper I sometimes use terminologically inappropriate term "Turks" or "Turk", because such form is used in the narratives about Peter Klepec. The correct term would be "Ottomans". For a more detailed explanation, see Pust, 2007, 210. 
non-Christian assistant (fairy, fairies, ${ }^{8}$ ox), and those that combine both types of

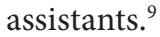

The heroism of Peter Klepec was particularly confirmed in his struggle against the Turks. Tales of Peter Klepec do not determine when this took place; however, the Turks really ravaged and wrought havoc across the country in the $15^{\text {th }}$ and $16^{\text {th }}$ centuries (see, for example, Simonič, 1971). Although they have never conquered or annexed these places under the Ottoman's reign, the Turks repeatedly plundered, burned down villages, and took inhabitants captive. Because of this, many places were desolated, while inhabitants emigrated to the Kočevsko and White Carniola (Bela Krajina) regions (Primc, 1995, 11). Many place names and stories associated with names given to places are nowadays still reminiscent of the Turkish raids. According to one of the stories, the Turks once came to Osilnica and offered oats for the horses to nibble right off the altar of Osilnica Church. When Klepec heard this, he uprooted a tree and used it to thresh the Turks, thus driving them from the territory. Nowadays, the name of the "Turki" (Turks) village reminds us of this event (Primc, 1995, 19). The still-present memory of the Turks is evidenced by the fact that the inhabitants of the valley even today say when someone steals something that they "acted like a Turk, to turcisized sth." (slov. "poturčil") (Slavko, 2014). Furthermore, the narratives of Klepec also feature a myth of the Ottoman invasions which is very important in terms of Slovenian national identity (see Bartulovič, 2012), which I will discuss in more detail later in this paper.

The fame of Klepec even reached the ears of imperial Vienna. In order to prevent a military conflict, Klepec struggled with the strongest Turkish soldier, vanquished him, and thus saved the Austrian Empire from the Turks (see for example Poženčan, $1847,84)$. By way of gratitude, the emperor granted him the right of free hunting and exempted him from paying taxes, or even gave him a title of nobility. In such stories about Peter Klepec, we come across the features of the so-called Hapsburg myth because Klepec acts as the saviour of the empire - as did later Levstik's Martin Krpan, about whose mythologisation wrote Bojan Baskar (2008). In my mind's eye, both Krpan, as Baskar noted, and Klepec represent "an image of the exemplary, devoted, transnational rural people, who remained faithful to the Empire until the last breath" (Baskar, 2008, 87). Worship of Hapsburg rulers was in varying degrees characteristic

8 Klepec found a dormant girl (in some stories even two or three) sleeping on a clearing. So that the scorching sun would not burn her face, he tore off the branches of a tree to make a shade. Out of thankfulness the girl, who was in fact a fairy, fulfilled his wish to become very strong.

9 Čater (1995) "combined” the notions of Christian and non-Christian assistants. According to his version of the story, Klepec pleaded to God for strength, whereby a fairy appeared fulfilling his wish. According to the narrative of Jože Ožura $(2002,7)$, Klepec turned to Mary for help on the Sveta gora, and God upon hearing his wish, fulfilled it through the good fairies. Therefore, a combination of several assistants is at play. 
of almost all Central European literature ${ }^{10}$ (Kos, 1991, 51), and also of Slovenian. ${ }^{11}$ Since the 1860s until the First World War, the Viennese (or imperial myth) acted as an idealized reference that characterised Central European societies. Austria was supposed to protect small nations and Europe against the Turkish danger (Velikonja, 1995, 31). However, German nationalism eventually led to the decline of the Austrian mission, and consequently to a destruction of the awareness of belonging to Central Europe $^{12}$ (Bučar, 1991, 61).

Did Peter Klepec really exist? Was he a real or fictional hero? There is not any material evidence of his existence. The inhabitants of the valley mostly believe that once there really lived a very mighty man (Primc, 1995, 6), but they do not attribute any supernatural powers to him (Mirjana, 2014; Slavko, 2014).

\section{The "revival" of Peter Klepec - or whose hero is Peter Klepec?}

The Čabransko-Osilnica region, is where the character of Peter Klepec developed, changed and persevered over the centuries, and was at different times and under different rulers often administratively united, as well as divided. Administratively, it belonged to the Dominion of Gotschee that stretched "over the Kočevsko region to Grobničko polje (field)" and most of the time belonged under one ruler: the patriarchs of Aquileia, the Ortenburgs, and Cillis. Only after the extinction of the latter, when the part of the Dominion was usurped by the Frankopans and Zrinskis (from the $16^{\text {th }}$ to the $18^{\text {th }}$ century), it was divided into Croatian and Slovenian parts (Primc, 1997, 7-12), or between the Austrian and Hungarian part of the Hapsburg Empire (Smole, 2014, 24). Since Slovenian independence in 1991, the inhabitants of the valley are separated by the border between Slovenia and Croatia, ${ }^{13}$ which has brought quite a few problems and promoted national divisions. Prior to this, they have not been as pronounced, since the valley was a culturally linked area, where residents still speak a common dialect, called the "speeches in the Čabranka and Upper Kolpa valley"14 (Smole, 2010, 29).

10 For details on the Hapsburg myth in Austrian literature, see Magris (2001).

11 For details on the Slovenian Hapsburg myth, see Kos, 1991, 41-53.

12 For details, see Bučar, 1991, 55-65.

13 In his book Kje se slovensko neha in hrvaško začne, Marko Zajc (2006) wrote extensively on the Slovenian-Croatian border and relations.

14 Naming of the dialect as "speeches in the Čabranka and Upper Kolpa valley" is used because its speakers do not identify with the official designation of the dialect, i.e., the "Kostel dialect" (Smole, 2010, 28). The development of the dialect was most strongly influenced by dialects from various regions of the Upper Carniola (Kranjska) region, the dialect of the Gottschee Germans, and to a lesser extent also by dialects of immigrants from Croatia and other places (ibid., see also Primc, 1997, 12-16). 
Up until the 1980s Peter Klepec was, together with his (remote and economically impoverished) valley, almost forgotten because according to Primc (1991, 5): "Fairytales were not desirable (arguing that they are making people dumb), since socialism cannot be built on the basis of fairytales." However, the Municipality of Osilnica then decided to name the territory of the municipality "The Land of Peter Klepec", which would primarily serve for promotional purposes and for promoting tourism. ${ }^{15}$ This kindled controversy over whose hero Peter Klepec actually is, which persists to this day. Interest in him awakened in the Croatian part of the valley in 1990 (Primc, 1991, 5), when the Klepec family originating from the house in Mali Log requested that a "purely honest account" about Peter Klepec should be written down which is also why Primc decided to write his book Peter Klepec in njegova dežela (Peter Klepec and his country). However, as we will see below, giving an "honest account" can be very complex. None of the stories explicitly mentions the national origin of Klepec, but they rather differ in where he lived and where he was born. As regards to his place of birth ${ }^{16}$ or residence, two options seem to emerge: namely, that he was born in Osilnica (e.g. Bevk, 1963; Poženčan, 1847) or its surroundings; or that he was born on the Croatian side of the border in Mali Log (see Primc, 1991; 2006) or Čaber (e.g., Čater, 1995; Vertec, 1880). Supposedly, a small house stood in Mali Log already from the $12^{\text {th }}$ century, apparently built by Klepec. He brought an enormous beam from the Holy Mount, which served for roofing. In his 1898 work Gorski kotar: slike, opisi i putopis (Gorski kotar: Images, Descriptions and Travelogue), the Croatian travel writer Dragutin Hirc wrote that he had seen inscribed on the birthplace of Peter Klepec the year 1712, as well as the aforementioned beam (Hirc, 1993, 146-149). During World War II, in 1942, the village was burned down by the Italian Army. The house of Klepec also burnt down. However, even to this day the former residents of this house claim to be descendants of Peter Klepec. Primc $(1991,20)$, who talked to them, writes that according to oral tradition the said house has been owned by the Klepec family around 820 years before the burning. In front of the house now stands a monument - a statue of Peter Klepec, carrying the beam.

In August 2014, I attended a literary evening of a local writer and poet Zlatko Pohobradsky at Palčeva šiša in Plešce on the Croatian side of the valley. After reading excerpts from his works, an interesting discussion developed as to whom Peter Klepec actually belongs. A falling out about the origin of Klepec almost occurred among the participants of the debate from both sides of the border, who know each other and otherwise foster good relations. They responded to my somewhat provocative question whether they believe that Peter Klepec connects or divides the inhabitants of the valley

15 Under this name, the municipality is promoted even today.

16 The information of the death of Klepec can be found in Hirc (1993, 149): supposedly he died in Budim, 85 years old. 
with a half-joking, but nevertheless serious answer: "At the moment, he obviously divides us." Then they told me that such division was not known to them before 1991. Therefore, Peter Klepec "has become" a Slovene or Croat only after the establishment of the border regime, and the consequent increase in ethnic discrimination (on this, see, e.g., Primc, 2006, 32, Kneževič Hočevar, 1999, 201).

Trying to resolve the dilemma of whether Peter Klepec was a Croat or Slovene seems absurd. He is claimed by the inhabitants of the valley on both sides of the border. That is, Klepec is Slovenian for Slovenes, and Croatian for Croats. In my opinion, it would be most correct if he was seen as a common hero of all the inhabitants of the valley. According to Smole (2014), these places have been characterised by specific identification before Slovenian independence because the residents are still reluctant to define themselves as Slovenes or Croats. However, if they have to identify themselves, they decide on a situational basis, depending on which identification seems more suitable to them at the given moment. In this area, identifying with "Slovenianness" or "Croatiannes" is ambivalent and is reflected in a "more or less rich repertoire of identity sources and in a more or less complex manner of handling them" (Knežević Hočevar, 1999, 211). Therefore, I believe that in the past it did not matter to which nationality Klepec belonged. What was important was his contribution to the community, which in difficult times identified with him, irrespective of the border. In fact, the inhabitants of the valley shared a common destiny for centuries (Ottoman raids, wartime internment, marginalisation, and underdevelopment of the region) in which ethnicity did not play a (greater) role. In 1991, Primc $(1991,7)$ noted the following regarding the relationship ${ }^{17}$ between the inhabitants of the valley:

Children of this region are still visiting the school which is closer and cheaper. Thus, in some parts Slovenes visit Croatian elementary schools and Croats the Slovenian ones. [...] It is similar with employment. Even more Croats than Slovenes are employed in the LIV plant in Osilnica; and more Slovenes are employed in Plešce on the Croatian side, etc. The artificial republic border which divided the Land of Peter Klepec between the two republics is no obstacle to prevent people from marrying, having fun together, offering a hand and cooperation. Even the deceased are sometimes buried regardless of the republic borders, not to mention visiting of churches. In addition, some Slovenes even have their telephone connection provided by the Croatian Post and vice versa, and the same is also true for electricity and other matters.

17 However, it can also be found in the stories of the inhabitants of the valley, collected and edited by Marija Makarovič, and depicted in the very title of the book - Dva bregova, eno srce ("Two banks, one heart"). 
However, in 2006 he already mentions the difficulties caused by the border (Primc, 2006, 32):

People (in Croatia) are being forced to identify themselves as Slovenes or Croats. [... ] They have successfully divided pupils, so that Slovenes drive only to Slovenian and "Croats" 18 to Croatian schools. It is similar with employment. [...] Before the road ran by Kolpa and Čabranka, partly on the Slovenian and partly on the Croatian side. Today they made a traffic arrangement on the Slovenian and another on the Croatian side. [...] Thus, politicians divide a once-unified Gebarija region into Slovenian and Croatian, and in this way divide the people as well.

Since Slovenian independence, matters therefore are not as straightforward anymore. Otherwise, the border between Slovenia and Croatia existed already within the former Austro-Hungarian Empire, and later the Socialist Federal Republic of Yugoslavia, but it "had a completely different administrative and political character" (Riman, Markelj, 2014, 128; see also Bufon, Markelj, 2010, 482), and did not present major problems to the inhabitants. By contrast, the bureaucratic procedures are today causing major problems to my interlocutors. Thus, many inhabitants of the border area do not even own a local border pass ${ }^{19}$ because the procedures are too complicated for them (Mirjana, 2014; Slavko, 2014; Smole, 2014). A once vibrant social life, which connected the people of Osilnica and Čaber (and, of course, the surrounding villages) has died out. For example, the residents of Čaber no longer go to dances in Osilnica. They venture across the border only occasionally to visit their relatives or the cemetery. Duška Knežević Hočevar $(1999,165)$ also found that the locals "see the new transnational border as a highly disruptive and divisive element". In recent years, the border regime has escalated, "especially with the introduction of the local border crossing near Zamost in 2007, and later the Schengen border regime which unfortunately has not eased up even after Croatia's entry into the European Union in 2013" (Smole, 2013, 25).

One might say that throughout the centuries Peter Klepec served as a symbol of strength and survival in these remote and economically disadvantaged locations. Besides the common dialect, Klepec is also one of the elements that still connects (albeit occasionally also divides them at the same time) the inhabitants of these locales, despite the difficulties brought about by the state border.

18 The quotation marks were added by the author of the quote.

19 In 2001, Slovenia and Croatia signed an agreement on border traffic and cooperation between the Republic of Slovenia and the Republic of Croatia (SOPS). A special local border pass was introduced for the population by the Slovenian-Croatian border (Bufon, Markelj 2010, 484) to facilitate crossing of the border. 
Peter Klepec is (was) a common hero of the inhabitants of the valley on both sides of the border, but as a national hero, he was however mainly manifested and preserved in Slovenia. In Croatia, he is less well-known because he is present only locally - on the Croatian side of the Čabranka-Osilnica valley. For example, Željko Malnar (2011) has written the following: "About Peter Klepac, or as he is called by the Slovenes Peter Klepec, more documents can be found in Slovenia than here. A renowned Slovenian writer has written a picture book about him, and RTV Ljubljana has recorded a radio show about this popular character for children." Probably the reason why Klepec is less popular in Croatia than in Slovenia lies especially in the fact that children are not taught about him, as is the case in Slovenia. Children from the Croatian side of the valley are only acquainted with him if the local hero is given some attention by the teachers (Mirjana, 2014). However, on the Croatian side of the Čabranka-Osilnica valley the myth of Klepec is handed down through oral tradition. ${ }^{20}$

\section{From the local to the national hero}

In Slovenia, the journey of Peter Klepec from a local to national hero began with various publications in the press, which had the purpose of encouraging national consciousness within the Slovenes. National awakening in the second half of the $19^{\text {th }}$ century meant, for the Slavic population of the Inner Austrian lands that did not have national awareness, "a radical break with the past and establishment of a new collective identity" (Jezernik, 2013, 7-8). ${ }^{21}$ Because the Slovenian bourgeoisie within the Hapsburg Monarchy was economically and politically too weak to be able to demonstrate a tendency to create their own country, it donned an apolitical mask, and seemingly focused solely on the concern for Slovenian culture (Jezernik, 2013, 7-8). Perception of culture as the most important means of the nation's selfrealisation was not unique to the Slovenians, but also of other Central European nations. "The culture should be the awakener of these nations, that in this ethnically fragmented territory prepared uprisings against foreigners, and which impacted the shaping of national and political consciousness. In other words, its associative agents: the nation was in this area constituted primarily as a cultural and linguistic community" (Velikonja, 1995, 30). The Slovenian nation, which was for centuries without political independence, and did not fight major wars, could build its national self-confidence only on "great men"22 (Jezernik, 2013, 8), which

20 Ana Perinić Lewis, PhD told me that the Croatian archives contain a number of manuscripts of stories about Peter Klepec that have been collected by Croatian ethnologists in the Gorski Kotar region.

21 For details about the Slovene national awakening, see Jezernik, 2008.

22 Preference was given to writers who wrote in the Slovenian language, for example, Vodnik, Trubar, and Prešeren (Jezernik, 2013, 9). 
were usually literary figures. Simoniti even notes that in Slovenia there formed a mythology of "quasi heroes", since "Slovenes did not have major generals and politicians", our "enlightened people" were not of a true religion or of Slovenian descent, so we did not have the right historical persons which could be uplifted into heroes. According to him, the "false" Slovenian heroes are the following: King Matthias, Peter Klepec, and Martin Krpan. "Awareness about the country, the Slovenian language, and the 'famous history' of Turkish struggles from the $15^{\text {th }}$ to the $18^{\text {th }}$ century, offered enough material to the $19^{\text {th }}$ century ethnographic romanticism, romantic historiography, and national enthusiasm of intellectuals to recall (write) or create stories themselves that were in the distant past apparently related to the truth. This resulted in myths that have influenced the formation of national self-esteem" (Simoniti, 2003, 75-76).

The Spring of Nations in 1848 spurred the nationally conscious Slovenes to more intensive collecting of traditional folk material. This also includes the story of Peter Klepec which became topical again - this time not only locally but nationally. It was necessary to find a folk hero comparable to the heroes of other nations, who should serve as an example to Slovenes (Smole, 2012, 1). Below I present some examples of the nationalisation of the myth of Peter Klepec, while simultaneously touching upon the Hapsburg myth, and the myth of the Ottoman invasions, occurring side by side.

The story of Peter Klepec written by an unknown author was first published in Kmetijske in rokodelske novice (The Farming and Craft News) in 1846. The story entitled Peter Klepec, silni slovenski junak (Peter Klepec, a Mighty Slovenian Hero) talks about how Peter Klepec somewhere in the vicinity of Kraljevi vrh defeated the enemy's strongest hero, and thereby protected some unknown king. Inhabitants of Osilnica and some of the nearby Croatian villages were to be granted nobility by way of gratitude, but which "their elders lost through negligence". The author of the publication significantly names Klepec as "our mighty hero" and "heroic son of Slovenia", and expresses a desire that future researchers among the inhabitants of these places would also unearth a song about Peter Klepcu, as he says: "As Serbs and Montenegrins praise brave deeds of their heroes, the Croats and Slovenes also maintain a memory of their mighty heroes in the songs for the coming generations." The next issue of the Farming and Craft News includes the author, this time signed as Sevčan $(1846,204)$, analysing the story and trying to set it in a historical period. He sets it in the $13^{\text {th }}$ century at the time of Mongol invasions, before which the Hungarian King Bela IV fled at the time of the Battle at Grobničko polje (field). The author lists Klepec among the so-called "heroes of the Grobničko polje”. 
A year later, on 6 January 1847, the first collector of Slovenian tales and legends, Matevž Ravnikar - Poženčan, ${ }^{23}$ published another version of the story in the News entitled: Še ena povest od Petra Klepca (Yet Another Tale of Peter Klepec). It speaks of Peter as an illegitimate child of a poor mother, frail shepherd boy, to whom on a Midsummer's Eve an ox bestowed strength because he helped him in a fight against another ox. The story continues with the victory of Klepec over the Turkish giant, and consequent banishment of the Turks from the land. In this story Klepec already emerges as a protector of the emperor and (trans) national hero. Thirteen years later, in August 1860, the News re-published the story simply entitled Peter Klepec, in which the Austrian emperor is called a "graceful prince" and Klepec a "man that has no equal". The stereotypical use of adjectives and synonyms when it comes to the Turks is also interesting - for example, "haughty Turk" and "bloodthirsty Adversary" (Kratkočasnica, 1860, 244-245). From the publication occurring 12 years later, it is obvious that the perception of the "good emperor" and "evil Turk" took strong roots:

" 'I am Peter Klepec of Čuber and I cometh here to grapple with the Turkish giant, and if God giveth and by heroic mirth, I spare You and your beautiful country. The Graceful Emperor smileth bitterly shaking his head, methinks, a man of so youthful and frail looks, as Klepec had, how could he beat this golem Turk!" (Vertec, 1880, 138-139). ${ }^{24}$

This juxtaposition of good (emperor, empire) versus evil (external enemy, Turk), or potential threat to the empire by the Turkish enemy, has for many years fed and inspired the Hapsburg myth. ${ }^{25}$ In it Peter Klepec acts as a loyal emperor's bondsman (see the underlined text above) and saviour of the empire. Therefore, we can say that the existence of the Hapsburg myth required the existence of the myth of the Ottoman incursions. Although since 1683 the Ottoman Empire was no longer strong enough to seriously threaten the Hapsburg empire, Hapsburg propaganda, however, exaggerating the intensity of the Turkish threat and collective threat to Europe, enhanced the feeling of their own indispensability in the defence against the Turks (Jezernik, 2012, 19). With the awakening nations of Central and Southeastern Europe in the $19^{\text {th }}$ and early $20^{\text {th }}$ century, the latter fostered a metaphor of a bulwark, or "the sense that it was their nation who had borne the brunt of protecting Europe against the Ottomans".

23 For details about the work and life of Matevž Ravnikar - Poženčan, see Kropej, 2008a and Stanonik 2009, 153-156. There are 14 preserved handwritten notebooks of Poženčan kept by the National and University Library, Ljubljana [Ravnikar-Poženčan MS-483], wherein he writes of Peter Klepec in the second notebook, also published in Ravnikar 2005.

24 Underlined by the author of the paper.

25 The negative perception of the Ottomans was also spread by Valvasor, who, as noted by Simonič $(2008,56)$, through "physical and ideological confrontation" with the Ottomans, "indirectly through literature and the educational system influenced the Slovenian historical consciousness and identity". 
Slovenian writers have also emphasised the glorious Slovenian past and its service to Western nations. The period of the "Turkish wars" was considered a difficult one, but at the same time "the most heroic period of the Slovenian nation" (Jezernik, 2012, 21). In doing so, Peter Klepec came in very handy.

In the book Uciteljski tovariš (Teacher's companion) from 1877, we can observe the use of the saying "to be strong like Peter Klepec", which likely passed in general usage because five years later it was once more used in the book Slovenski gospodar (Slovenian master) (15 June 1882, 185). This probably means Peter Klepec had already been "seen as a symbol of the nation's heroic identity and generally adopted in the Slovenian area" (Smole, 2011, 4).

According to Kermauner, its usage in terms of "national formation" is of particular importance with respect to the formation of a national myth. "Klepec is a weakling who becomes a hero - and that is the basic task or desire of a newly emerging, and as of yet unrecognised small nation" (Kermauner, 1980, 921). In addition, Kermauner believes that after the first historic national institutionalisation of Slovenehood in 1945, playwrights did not feel the need to renew the nation-formative and societyformative aspect of the national myth. Moreover, according to him a "destruction of the national myth as an additional founder of the nation-state and nationalism, that is to say, also of the (special) social moral values of institutionalized civil nation" started already with Cankar. Indeed, the $20^{\text {th }}$ century marks a (partial) reversal, as the character of Peter Klepec started to be used (also) by writers who wanted to highlight the weakness of the Slovenian national character; but Klepec still remained a symbol of power. Let us take a look at some examples of the "destruction of the myth" (Kermauner, 1980, 922).

Ivan Cankar used the story of Klepec to display Slovenian servitude and humility towards foreign rulers. In his collection of novelettes Podobe iz sanj (Images from dreams), he tells a story up to the moment when Peter gained the power, and then says:

We do not know how the strong Peter Klepec fared. No writing exists, no announcement thereof of how he wielded his power: whether he terrorized and importuned his merciless masters, repaid them in kind; or whether he reigned the surrounding lands, waged war and vanquished the arrogant enemies throughout the wide world as did King Matthias. We are not aware of anything of the kind. It seems that he uprooted that old musty pear tree and then lived a calm, quiet, and faithful life he was accustomed to; he faithfully obeyed the master, drove his cattle to graze with a piece of bread in his trousseau, and served his companions and all the people with all of his strength and according to their commands. Had the benevolent God not 
only sent his angel from heaven, but awarded him with its infinite power, Peter Klepec would not know what to do with it; it would even get in his way (Cankar, 1917, 42-43).

Therefore, Cankar's Peter Klepec is a weakling, who on the one hand craves power, and on the other hand, fears it; so instead of using his power to save himself from the yoke of his masters, he rather continues to be the servant. Anton Ocvirk in his reflection from 1931 entitled Slovenski kulturni problemi (Slovenian Cultural Issues) wrote that Cankar in his Peter Klepec draws a tragedy of one of the bittermost Slovenian features - passivity. As the basic mythical symbols identifying Slovenian mental traits, Ocvirk stated Fair Vida (a symbol of yearning), Peter Klepec (a symbol of passivity), King Matthias (a symbol of expected salvation), and Kurent (a symbol of the Slovenian artist) (Ocvirk, 1931, 245-247; Stanonik 2009, 488-491). However, it cannot be said that Cankar's Peter Klepec "lost his power", but the variance in usage rather changed the symbolism of the myth, which depends on the context in which you want to use it. The historian Vasko Simoniti (2003, 77-79) also observes in the myth of Peter Klepec the personification of the Slovenian national character: "The hero only wants to show his power to his compatriots, which metaphorically means that the nation is trying to convince itself of its power, proving it can only serve as a loyal subject." Peter Klepec is similarly portrayed as a weakling and servant in the modern staging of the play by Luka Horvat, who says that one can infer about the values of the nation from Slovenian folktales:

Starting from Peter Klepec, one might say that these values are humility, servitude, lack of freedom, even slavery. If we are talking about a collective archetype, Peter Klepec could serve as an example of someone who has greater power, but nevertheless does not know how to use it to do away with servitude. Sometimes it is good that this servitude is present in a humorous way because then we can begin to laugh at our own doings. This already allows a different understanding of the world (Željan, $20^{\text {th }}$ of March 2014).

Despite a change of Peter Klepec into a symbol of weakness, he at the same time remained a symbol of power. After the World War II in 1946, France Kosmač (130) wrote a poem entitled "Prešernov rod" ("Prešeren's Tribe"), which extols Slovenian courage. One of the stanzas depicting Klepec as a metaphor of heroism, goes as follows:

No longer a servant, ,tis the son of Peter Klepec who embraced freedom, a magical fairy of the mountain born of the heroic spirit, born of the blood of heart! 
Probably the most famous written story about Peter Klepec is by Bevk in 1956. According to him, Klepec is a hero who has fought for the rights of his people already with the Hungarians (Magyars). Initially, he helped the Hungarian King Bela beat the Tartars (i.e., the Mongols - Bevk talks about Batu Khan) who invaded his kingdom and were also called "dogheads" (psoglavci) by the people (Bevk, 1963). ${ }^{26}$ When Klepec found out that his waiting on the king to fulfill his promises of payment is in vain, and even more so, that the Hungarians conquered the inhabitants of the valley and mistreated them, he was filled with anger and drove the Hungarians from the land. Therefore, this incident in the story involves a kind of uprising of Klepec as a representative of the oppressed inhabitants of the valley against the imposed Hungarian rule. However, as Bevk himself pointed out in his final note, certain incidents from the story are his own construct: "I tailored a tale so I could tell what I thought was important to tell at the time when there already lurked about many of our enemies and a lot of people felt despondent" (Bevk, 1963, 318). Probably these words of Bevk targeted the Italian occupation of the Slovenian Primorska region (where he was born) (see Lah, Inkret, 2002, 133). Thus, in his narrative about Klepec, he portrayed him as a model for all Slovenians as a proud, relentless, fearless, righteous hero who does not allow foreigners to intimidate him or his fellow countrymen.

Despite the frequent derisive relationship towards Peter Klepec as a symbol of Slovenians in Slovenian literature, his name is used for commercial purposes only to emphasize the strength of something. The use of the name "Peter Klepec" is widespread across broader Slovenia. ${ }^{27}$ For example, the following carry his name: the Osilnica adventure park, Slovenian Armed Forces helicopter, floating suction dredger in the Port of Koper, fitness centre, climbing wall course, and even a helpline for children and young people in need. He is also depicted as a playing card in the Slovenian Tarok. All in all, Peter Klepec is quite popular in Slovenia. There are books for children, a comic book, and cartoon and puppet show about him. In Osilnica ${ }^{28}$ he even has his own monument. The visibility and popularity of Klepec is certainly affected by the influence of stories about Peter Klepec in school curriculum.

26 The "dogheads" could have been the following (Šmitek, 2004, 296): 1 "savage people" living "on the borders of the inhabited world"; or "in inaccessible places in the home environment"; 2 "actual historical enemies", for example, Turks or three "demons or human degenerates", The designation of a "doghead" ("psoglavec") is clearly intended to emphasise the strangeness and inhumanity of the aggressor - or Tatars in Bevk's story.

27 I also looked for examples of usage in Croatia but I only found one, namely: the "KCA Peter Klepac" Autoclub. 


\section{Conclusion}

This paper shows that the myth of Peter Klepec and its interpretations are constantly changing, but nevertheless preserve themselves through oral tradition, through the words of raconteurs, and "in artistic creations and cultural representations of individuals and communities" (Kropej, 2008b, 9). The diversity of interpretations is primarily dependent on interpreters and historical circumstances. Thus, through the local hero from the time of the Ottoman invasions, which connected the members of two nations, we come to the pan-Slovenian "Cankarian" weakling who has been preserved to this day. On the other hand, Klepec in stories for children is depicted solely as a hero. His name is also used for commercial purposes only to emphasize the power of something. I agree with Meletinski (2006) who states that modern man would not exist without myths. In addition, it is not easy to eliminate myth, but it can be continued and reshaped, depending on what you want to say with it, or in what context you want to use it.

Translated by Miha Odar

\section{References}

Armstrong, K., Kratka zgodovina mita, Ljubljana 2005.

Bajec, A. et al., Slovar slovenskega knjižnega jezika, Ljubljana 1994.

Bartulovič, A., O pasteh dediščinskega pouka: Pouk zgodovine in literature kot konstrukcija Drugega, in: Živeti z dediščino: Zbornik referatov mednarodne konference (ed. Hirnök Munda, K., Rožman, H.), electronic book 2012, pp. 7079.

Baskar, B., Martin Krpan ali habsburški mit kot sodobni slovenski mit, Etnolog 18, 2008, pp. 75-93.

Bevk, F., Otroci samote, Ljubljana 1963.

Bevk, F., Peter Klepec, Ljubljana 2008.

Bučar, F., Srednja Evropa - mit ali stvarnost?, in: Srednja Evropa (ed. Vodopivec, P.), Ljubljana 1991, pp. 55-65.

Bufon, M., Markelj, V., Vpliv vzpostavitve schengenskega režima na prepustnost meje: primer slovensko-hrvaške meje, Annales. Series historia et sociologia 20 (2), 2010, pp. 481-494.

Campbell, J., Junak tisočerih obrazov, Nova Gorica 2007.

Cankar, I., Podobe iz sanj, Ljubljana 1917. 
Carlyle, T., On Heroes, Hero-worship and the Heroic in History, London, New York 1913.

Čater, D., Peter Klepec, Ljubljana 1995.

Frye, N., Anatomija kritištva, Ljubljana 2004.

Goljevšček, A., Pravljice, kaj ste?, Ljubljana 1991.

Grafenauer, I., Lepa Vida. Študija o izvoru, razvoju in razkroju narodne balade o Lepi Vidi, Ljubljana 1943.

Grafenauer, I., Slovenske pripovedke o Kralju Matjažu, Ljubljana 1951.

Hirc, D., Gorski kotar: slike opisi i putopisi, Rijeka 1993.

Hladnik, M., Pa začnimo pri Krpanu, Sodobnost 66 (2), 2002, pp. 227-237.

Hourihan, M., Deconstructing the Hero, London, New York 1997.

Hrženjak, M., Elementi družboslovne analize mita: ali je mogoča celovita analiza mita, Časopis za kritiko znanosti 27 (194), 2003, pp. 45-64.

Hrženjak, M., Interpretacija simbolnega: trije semiološki projekti, Časopis za kritiko znanosti 30 (209/210), 2002, pp. 379-397.

Jazbec, M., Martin Krpan: diplomat in vojščak, Studeno 2009.

Jezernik, B., Od vzpona nacije do nacionalizacije, in: Slovensko meščanstvo od vzpona nacije do nacionalizacije (1848-1948) (ed. Dežman, J., Hudales, J., Jezernik, B.), Klagenfurt 2008, pp. 17-66.

Jezernik, B., Imaginarni “Turek”, in: Imaginarni “Turek” (ed. Jezernik, B.), Ljubljana 2012, pp. 7-26.

Jezernik, B., Veliki možje in razvoj slovenskega narodnega vprašanja, in: Heroji in slavne osebnosti na Slovenskem (ed. Jezernik, B.), Ljubljana 2013, pp. 7-26.

Jocić, S., Problem mitologizacije znanosti, Časopis za kritiko znanosti 31 (211), 2003, pp. 186-198.

Kermauner, T., Obnova mita (in rituala) v današnji slovenski dramatiki, Sodobnost 28 (10), 1980.

Knežević Hočevar, D., Družbena razmejevanja v dolini zgornje Kolpe: domačinska zamišljanja nacije in lokalitete, Ljubljana 1999.

Kos, J., Srednja Evropa kot literarnozgodovinski problem, in: Srednja Evropa (ed. Vodopivec, P.), Ljubljana 1991, pp. 41-53.

Kosmač, F., Prešernov rod, Novi svet 1/4, Ljubljana 1946, http://www.dlib. si/?URN=URN:NBN:SI:DOC-RWE9JPTD [18. 9. 2014].

Kratkočasnica, Peter Klepec, Kmetijske in rokodelske novice 18 (31), $1^{\text {st }}$ of August 1860, http://www.dlib.si/?URN=URN:NBN:SI:DOC-5HBLQ0RG [25. 10. 2014]. 
Kropej, M., Pravljica in stvarnost: odsev stvarnosti v slovenskih ljudskih pravljicah in povedkah ob primerih iz Štrekljeve zapuščine, Ljubljana 1995.

Kropej, M., Metamorfoze ljudskega pripovedništva na Gorenjskem, Traditiones 37 (2), 2008a, pp. 169-216.

Kropej, M., Od ajda do zlatoroga: slovenska bajeslovna bitja, Klagenfurt, Ljubljana, Vienna 2008b.

Kropej, M., Narrative tradition about King Matthias in the process of transformation, Slovenský národopis [Slovak Ethnology] 2 (62), 2014, pp. 244-258.

Lah, K., Inkret, A., Slovenski literarni junaki, Ljubljana 2002.

Magris, C., Habsburški mit v moderni avstrijski književnosti, Trieste 2001.

Makarovič, M. (ed.), Dva bregova, eno srce: življenjske pripovedi iz doline Kolpe in Čabranke, Kočevje 2002.

Malnar, Ž., Peter Klepec, silni “slovenski” junak, 2011, http://www.croinfo.net/vijestiregija/5933-petar-klepac-legenda-ili-istina.html [25. 5. 2014].

Meletinski, J., Poetika mita, Ljubljana 2006.

Mirjana, Intervju, Trstje 2014.

Ocvirk, A., Slovenski kulturni problemi, Ljubljanski zvon 51 (4), 1931, http://www. dlib.si/?URN=URN:NBN:SI:DOC-28RJXZI6 [18. 9. 2014].

Ovsec Damjan J., Fair Vida. Interdisciplinarian ethnological interpretation. The everlasting importance of the psychological aspect of the Slovene ballad, Studia mythologica Slavica 1, 1998, pp. 265-277.

Ožura, J., Peter Klepec, Osilniška dolina 18, Osilnica 2002.

Peter Klepec, silni slovenski junak, Kmetijske in rokodelske novice, $7^{\text {th }}$ of January 1846, p. 204.

Poženčan - Ravnikar, M., Še ena povest od Petra Klepca, Kmetijske in rokodelske novice 5 (21), $26^{\text {th }}$ of May 1847 , p. 84.

Primc, J., Peter Klepec in njegova dežela, Kočevje 1991.

Primc, J., Okamneli mož in druge zgodbe iz Zgornje Kolpske doline (od Babnega Polja in Prezida prek Gerova, Čabra, Osilnice, Kužlja, Kostela, Fare do Dola in Predgrada), Ljubljana 1997.

Primc, J., Naši na Hrvaškem ali izgubljeni Slovenci, Kočevje 2006.

Pust, K., Podoba “Turka” v krščanskih deželah vzhodnega Jadrana v zgodnjem novem veku, Acta Histriae 15 (1), pp. 209-234.

Ravnikar, M., Poženčanove pravljice: najstarejše slovenske pravljice in povedke (ed. Stanonik, M.), Radovljica 2005. 
Riman, B., Markelj, V., “Živ Hrvat, mrtev Slovenec”: vpliv meje na prebivalstvo na primeru občine Ilirska Bistrica in Kvarnerja, in: Ponovno iscrtavanje granica: transformacije identiteta $i$ redefiniranje kulturnih regija u novim političkim okolnostima, 12. hrvatsko-slovenske etnološke paralele (ed. Belaj, M. et al.), 2014, pp. 127-148.

RTV SLO, Peter Klepec - Slovenec ali Hrvat?, Nedeljski izlet, Val 202, $2^{\text {nd }}$ of November 2014, http://ava.rtvslo.si/predvajaj/peter-klepec-slovenec-ali-hrvat/ ava2.174302272/ [10.11.2014].

Sevčan, Peter Klepec, silni slovenski junak, Kmetijske in rokodelske novice, $23^{\text {th }}$ of December 1846, p. 204.

Simonič, I., Zgodovina mesta Kočevja in Kočevske, in: 500 let mesta Kočevje (ed. Kotar, H. et al.), Kočevje 1971, pp. 5-51.

Simonič, P., Nacionalizacija fevdalne ideologije J. V. Valvasorja, Glasnik SED 49 (3/4), 2008, pp. 52-58.

Slavko, Intervju, Trstje 2014.

Slovenski gospodar: podučiven list za slovensko ljudstvo, 15. 6. 1882, http://www.dlib. si/?URN=URN:NBN:SI:DOC-CLYRCF55 [25. 10. 2014].

Smith, A. D., Myths and Memories of the Nation, Oxford 1999.

Smole, M., Govori ob Čabranki in zgornji Kolpi, in: ŽIVA kulturna dediščina se predstavi (ed. Križnar, N.), Ljubljana 2010, pp. 28-31.

Smole, M., Časopisne objave o Petru Klepcu, Plešcih in Sveti Gori v časopisih iz 19. stoletja in do druge svetovne vojne: Članek k razstavi v Etnološki zbirki Palčeva šiša, Plešce, 2009-2011, unpublished material, 2012.

Smole, M., Stavbna dediščina v dolini zgornje Kolpe in Čabranke, Plešce 2013.

Smole, M., Intervju, Plešce 2014.

Stanonik, M., Zgodovina slovenske slovstvene folklore: Od srednjega veka do sodobnosti, Ljubljana 2009.

Svein Stugu, O., Myths, History and the Construction of National Identity, European Summer University conference The Misuse of History, Strasbourg 2003, https:// www.academia.edu/6159236/Myths_History_and_the_Construction_of_National_ Identity [25. 2. 2015].

Šaver, B., Šport, mitologija in genealogija junaštva: Kritična branja športa v kulturnih študijah, Monitor ISH VIII (1), 2006, pp. 71-86.

Šmitek, Z., Mitološko izročilo Slovencev: Svetinje preteklosti, Ljubljana 2004.

Šmitek, Z., Moč ti je dana: Slovenske pripovedi o junakih in zgodovinskih osebnostih, Radovljica 2005. 
Šmitek, Z., Kralj Matjaž: mavrični sij ljudskega junaka, Acta Histriae 17 (1/2), pp. 127 140.

Špelec, S., Kekec: Med literarnim junakom in filmsko zvezdo, in: Heroji in slavne osebnosti na Slovenskem (ed. Jezernik, B.), Ljubljana 2013, pp. 229-246.

Velikonja, M., Mitologija srednje Evrope, Časopis za kritiko znanosti 176, 1995, pp. 27-43.

Velikonja, M., Masade duha: Razpotja sodobnih mitologij, Ljubljana 1996.

Velikonja, M., Mitografije sedanjosti: Študije primerov sodobnih političnih mitologij, Ljubljana 2003.

Vertec, Peter Klepec, Vertec, $1^{\text {st }}$ of September 1880, http://www.dlib.si/details/ URN:NBN:SI:DOC-30GHGT79 [25. 5. 2014].

Vezovnik, A., Kritična analiza diskurzivne konstrukcije kolektivnih identifikacij: Primer slovenstva, Doktorska disertacija, Fakulteta za družbene vede, Ljubljana 2009.

Zupan Sosič, A., Heroji in herojinje v sodobnem slovenskem romanu, in: Heroji in slavne osebnosti na Slovenskem (ed. Jezernik, B.), Ljubljana 2013, pp. 213-228.

Željan, K., Slovenci ne bi smeli biti kot Peter Klepec: Pravljice za odrasle: Luka Hrovat in Mirjam Štih univerzalne motive iz ljudskih pravljic postavljata v sodobni čas, Delo, $20^{\text {th }}$ of March 2014, http://www.delo.si/druzba/panorama/slovenci-ne-bismeli-biti-kot-peter-klepec.html [25. 5. 2014]. 
Anja Moric

\section{Peter Klepec: od (lokalnega) junaka do (nacionalne) prispodobe šibkosti}

Ključne besede: Peter Klepec, junak, mit, meja, nacionalizem

Pripovednega junaka Petra Klepca poznajo (in si ga lastijo?) prebivalci Čabranskoosilniške doline, torej obmejnega območja na hrvaški in slovenski strani meje. O njem kroži več med seboj precej podobnih zgodb, v katerih šibek nezakonski otrok Peter postane silak, ki s svojo nadnaravno močjo pomaga pomoči potrebnim in iz krajev odganja sovražnike. Prispevek na primeru ljudskega in literarnega junaka Petra Klepca prikaže spreminjajočo se vlogo in različnost interpretacij mita v času in prostoru. Osredotoča se na zgodovinske spremembe v dojemanju Petra Klepca: na njegovo (lokalno) funkcijo v času imperialne politike Habsburžanov, na proces njegove nacionalizacije in dileme, ki so se pojavile ob delitvi Čabransko-osilniškega območja t. j. izvirnega območja nastanka legend med dve državi (Slovenijo in Hrvaško). Pokaže, da se je zaradi različnih zgodovinskih okoliščin in (interpretativnih) diskurzov Klepca uporabljalo v različne namene. Najprej je služil kot simbol moči in preživetja v Čabransko-osilniški dolini, nato kot habsburški mit, ki je opravičeval obstoj monarhije nasproti osmanskemu sovražniku in slednjič kot prispodoba hlapčevskega Slovenca, ki je vedno le vdan podložnik drugim gospodarjem (najprej Avstro-ogrski, nato Evropski uniji). 


\section{Anja Moric \\ Peter Klepec: from a (Local) Hero
to a (National) Allegory of Weakness}

Keywords: Peter Klepec, hero, myth, border, nationalism

The narrative hero Peter Klepec is known (and laid claim to) by the inhabitants of the Čabranka-Osilnica valley, the border area on the Croatian and Slovenian side of the border. There circulate a number of quite similar stories about him, in which a frail illegitimate child Peter becomes a strong man, whose supernatural powers help the needy and drive the enemies from these regions. This paper shows the changing role and diversity of interpretations of myth in time and space using the example of folk and literary hero Peter Klepec. It focuses on the historical changes in the perception of Peter Klepec: namely, on his (local) function at the time of the Hapsburg imperial policy, the process of his nationalisation and dilemmas that arose following the division of the Čabranka-Osilnica area, i.e., the originating area of the creation of the legend of the two countries (Croatia and Slovenia). It shows that Klepec was due to different historical circumstances and (interpretive) discourse used for different purposes. First, he served as a symbol of strength and survival in the Čabranka-Osilnica valley, and then as the Hapsburg myth that justified the existence of the monarchy facing the hostile Ottomans, and lastly as an allegory of a servile Slovene, who is always just a faithful bondsman to other masters (first under the Austro-Hungarians and then the European Union). 